\title{
REVIEW
}

\section{Endothelial cells and coagulation}

\author{
Katharina Neubauer ${ }^{1}$ D $\cdot$ Barbara Zieger $^{1}$
}

Received: 24 February 2021 / Accepted: 28 April 2021 / Published online: 20 May 2021

(c) The Author(s) 2021

\begin{abstract}
Endothelial cells form a monolayer, which lines blood vessels. They are crucially involved in maintaining blood fluidity and providing controlled vascular hemostasis at sites of injury. Thereby endothelial cells facilitate multiple mechanisms, including both procoagulant and anticoagulant, which must be kept in balance. Under physiological conditions, endothelial cells constitute a nonadhesive surface preventing activation of platelets and the coagulation cascade. Multiple fibrinolytic and antithrombotic properties act on their cell surface contributing to the maintenance of blood fluidity. These include platelet inhibition, the heparin-antithrombin III system, tissue factor pathway inhibition, thrombomodulin/protein C system, and fibrinolytic qualities. At sites of vascular damage, platelets react immediately by adhering to the exposed extracellular matrix, followed by platelet-platelet interactions to form a clot that effectively seals the injured vessel wall to prevent excessive blood loss. For solid thrombus formation, functional platelets are essential. In this process, endothelial cells serve as a support surface for formation of procoagulant complexes and clotting. This review gives an overview about the central role of the endothelium as a dynamic lining which controls the complex interplay of the coagulation system with the surrounding cells.
\end{abstract}

Keywords Hemostasis $\cdot$ Thrombosis $\cdot$ Platelets $\cdot$ Von Willebrand factor $\cdot$ Endothelial injury

\section{Background}

The endothelium is a monolayer of cobblestone-shaped cells, which covers the inner wall of blood vessels separating the lumen from the surrounding tissue as a cellophanelike barrier. Although the endothelium is $<0.2 \mu \mathrm{m}$ thick, it weights approximately $1 \mathrm{~kg}$ in an average-sized human and covers a total surface area of 4000 to $7000 \mathrm{~m}^{2}$ (Wolinsky 1980). Endothelial cells (ECs) are central and active parts of two major systems in the body - the immune and the vascular system. Depending on the tissue of origin, structure of the ECs varies (Gomez-Salinero and Rafii 2018). The functions of ECs are versatile and include regulating transport from the blood to underlying cells and tissues, permeability, vascular tone, cellular adhesion, smooth muscle cell proliferation, angiogenesis, and vessel wall inflammation. ECs are able to respond to physical and chemical signals

Barbara Zieger

barbara.zieger@uniklinik-freiburg.de

1 Department of Pediatrics and Adolescent Medicine, Division of Pediatric Hematology and Oncology, Medical Center, Faculty of Medicine, University of Freiburg, Freiburg, Germany by production of a wide range of factors that regulate these processes.

This review focuses on specific functions and adaptations of ECs maintaining blood fluidity as well as preventing thrombus formation and extravascular blood loss. This is only possible because ECs actively regulate the blood coagulation system and the production of solutes, hormones, or macromolecules (Mehta and Malik 2006).

\section{Endothelial cell function}

\section{Platelet inhibitory properties of the endothelium}

Contact between healthy vascular ECs and blood does not lead to adherence of platelets or clot formation, and this is not a passive phenomenon. Platelets circulate through the vascular tree in a resting state until they are needed. Therefore, ECs provide an anticoagulant and antithrombogenic boundary layer and produce actively substances that directly regulate platelet activity (Fig. 1).

One of these products that is continuously synthesized by ECs and that inhibits platelet adhesion and aggregation is nitric oxide (NO) (Radomski et al. 1987). This gas 


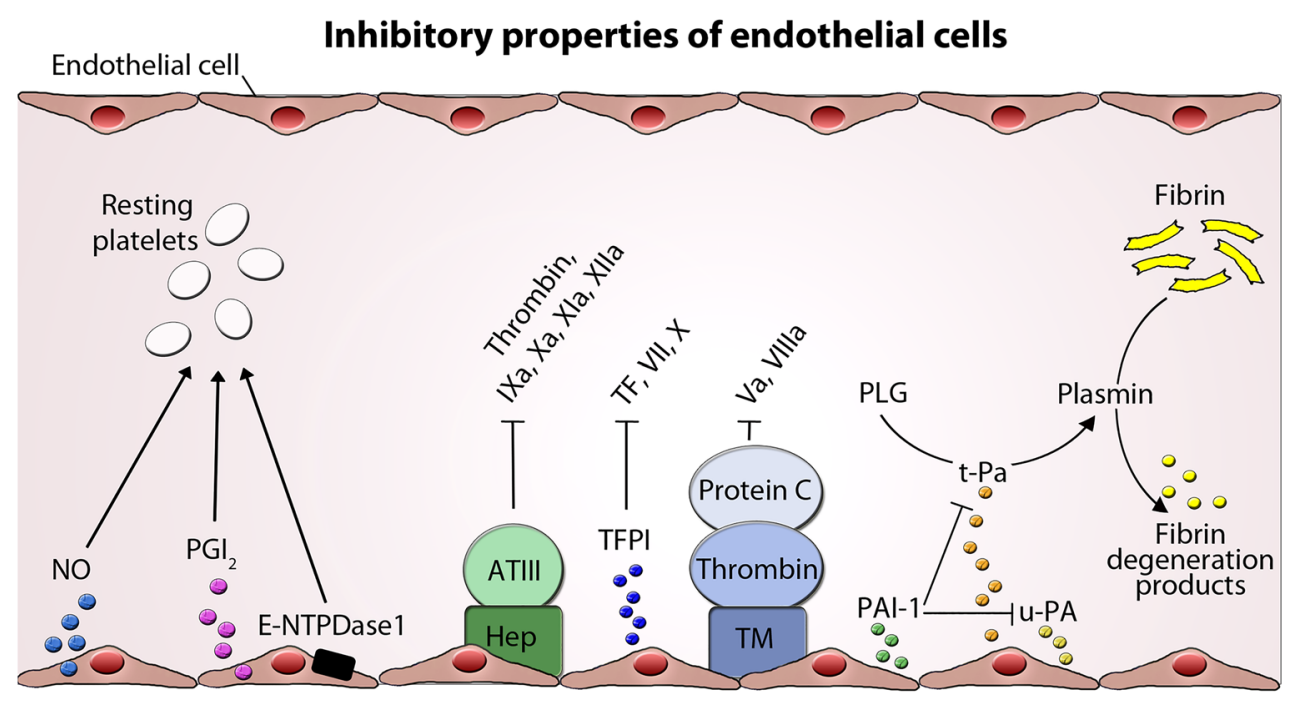

Fig. 1 Inhibitory properties of endothelial cells. Inhibition of platelet function and coagulation by several endothelial molecules and factors and the targeted coagulation factors are shown. Endothelial cells (ECs) express nitric oxide (NO), prostacyclin $\left(\mathrm{PGI}_{2}\right)$, and ectonucleoside triphosphate diphosphohydrolase-1 (E-NTPDase1), which inhibit platelet adhesion and aggregation. Heparin-like molekules (Hep) expressed on endothelial surface serve as a cofactor for antithrombin III (ATIII) inactivating several coagulation factors. ECs express tissue factor pathway inhibitor (TFPI), which limits the action of tissue factor (TF) and inhibits excessive TF-mediated activation of coagulation factors VII and X. Thrombomodulin (TM) binds thrombin activating protein $\mathrm{C}$ and degrades factor Va and VIIIa. Activation of fibrinolysis by endothelial tissue plasminogen activator (t-PA) and urokinase-type plasminogen activator (u-PA) and their inhibition by plasminogen activator inhibitor (PAI-1) is depicted. PLG plasminogen

protein-coupled receptor, which in turn activates intracellular adenylate cyclase (AC). Consequently, this increases the intracellular level of cyclic adenosine monophosphate (cAMP), which ultimately leads to activation of protein kinase A (PKA) and direct inhibition of $\mathrm{Ca}^{2+}$ mobilization and platelet granule release (Braune et al. 2020). These events limit the ability of platelets to respond to procoagulant stimuli, thereby preventing interactions with the intact vessel wall. In smooth muscle cells, PKA promotes the phosphorylation of the myosin light chain kinase, which inhibits it and leads to smooth muscle relaxation and vasodilation (Fetalvero et al. 2007). Although $\mathrm{NO}$ and $\mathrm{PGI}_{2}$ have different mechanisms of action, they synergize with each other to inhibit platelet activation and aggregation (Radomski, Palmer and Moncada 1990).

The purinergic nucleotides adenosine triphosphate (ATP), adenosine diphosphate (ADP), and adenosine monophosphate (AMP) are constitutively released from ECs at low rates, which increase at sites of vascular injury or stress. Soluble ADP released from activated platelet granules is a potent mediator for recruiting and amplifying platelet aggregation during the formation of a hemostatic plug. To regulate the activity of this agonist, vascular ECs express ectonucleoside triphosphate diphosphohydrolase-1 (E-NTPDase1/ CD39), a membrane-bound enzyme that converts ATP and ADP into adenosine (Deaglio and Robson 2011; Marcus et al. 1991). In this way, ECs limit the prothrombotic signals and exert a potent, protective vascular effect. 


\section{Heparin-antithrombin III system}

A strong stimulator of platelets is thrombin (factor II), a serine protease, which is the final effector of the coagulation system and is locally produced (Mann et al. 2003). Once the coagulation has started to generate thrombin, it becomes highly amplified. Therefore, it is important that the endothelial surface provides proteins, which inhibit thrombin and counteract the progress of coagulation. Such a potent inhibitor of thrombin is the liver-derived plasma protein antithrombin III (ATIII) (Anastasiou et al. 2012). ATIII forms a complex with thrombin and other serine proteases, such as clotting factors IXa, Xa, Xia, and XIIa, and regulates them by preventing the active site of these proteases from coming into contact with their substrates. The activity of ATIII is markedly promoted by heparan sulfates (Ofosu et al. 1984). ATIII binds to specific heparan sulfates of proteoglycans in the glycocalyx that covers the endothelial surface (Bauer \& Rosenberg 1991). In humans, the importance of this system has been highlighted by the occurrence of thrombotic diseases in patients with ATIII deficiency (Towne et al. 1981).

\section{Tissue factor pathway inhibition}

Tissue factor (TF, factor III), a transmembrane protein, primarily expressed in extravascular cells and platelets but is also present in subendothelial tissue. Its role in the clotting process is the initiation of thrombin formation from prothrombin. To prevent coagulation at the top of the cascade, healthy ECs express tissue factor pathway inhibitor (TFPI), a serine protease, which limits the action of TF and inhibits excessive TF-mediated activation of coagulation factors VII and X (Girard and Broze 1993).

\section{Thrombin receptor thrombomodulin and the protein $\mathrm{C} / \mathrm{S}$ system}

To mitigate the procoagulant properties of thrombin, ECs additionally synthesize constitutively thrombomodulin (TM), a membrane-bound thrombin receptor, which directly decrease the levels of circulating thrombin (Hofsteenge et al. 1986). Upon binding to TM, thrombin undergoes a conformation change, resulting in enhanced affinity for protein $\mathrm{C}$, which acts as an anticoagulant. Activated protein $\mathrm{C}$ forms a complex with protein $\mathrm{S}$ and inactivates the clotting factors Va and VIIIa (Stern et al. 1986). Thrombin bound to TM has reduced ability to convert fibrinogen to fibrin and to promote platelet aggregation (Adams and Huntington 2006). TM serves as a cofactor in the thrombin-induced activation of protein $\mathrm{C}$ anticoagulation pathway. Deficiency of protein $\mathrm{C}$ in humans has been associated with thrombotic diseases (Griffin et al. 1981). Activated protein C binds further tissue plasminogen activator inhibitor-1 (PAI-1), which was synthesized and released by ECs and plays an important role in determining the overall rate and extent of fibrinolytic process (Loskutoff and Edgington 1981).

\section{Fibrinolytic properties of the endothelium}

ECs provide a mechanism, which counteracts the accumulation of fibrin, the result of coagulation by producing and releasing continuously tissue-type plasminogen activator (t-PA) and urokinase-type plasminogen activator (u-PA). t-PA and $\mathrm{u}-\mathrm{PA}$ are serine proteases, which activates fibrinolysis by cleaving the liver-derived plasminogen (PLG) and converting it into plasmin (Loskutoff and Edgington 1977). The broadly acting protease plasmin in turn degrades crosslinked fibrin into fibrin degradation products. In this way, t-PA monitors the patency of blood vessels and removes through fibrinolysis hidden deposition of fibrin in the vessels. Modulation of t-PA release by stress, venous occlusion, thrombin, histamine, and cytokines is thought to influence directly the rate of fibrin dissolution. Furthermore, t-PA becomes acutely released from storage organelles after exposure of ECs to vasoactive agents or thrombin. The rate of fibrinolysis is limited by the steady-state availability of t-PA during fibrin-polymerization. The efficacy of t-PA within the plug is much higher than that of t-PA molecules added from outside to existing plug (Medcalf 2007). In general, the repertoire of all these coagulation inhibitors expressed in ECs can vary according to different organs and even within the vasculature of an organ (Aird 2015).

\section{Endothelial injury}

\section{Hemostasis}

At sites of vascular injury, the endothelium shifts from an anticoagulant to a procoagulant/prothrombotic phenotype to prevent excessive blood loss. Vasoconstriction is an important initial response when the vessel is damaged. It is caused by direct exposition of smooth muscle cells to locally generated vasoactive agents, such as bradykinin, histamine, vasopressin, or thrombin, and by bypassing the vasodilatory action of ECs (Durand and Gutterman 2013). This leads to reduction of the vessel diameter and a slowdown in blood flow, which is the hemodynamic basis for subsequent processes. Coagulation begins almost instantly, a process resulting in hemostasis, the cessation of blood loss, followed by repair. In hemostasis, two components are involved, platelets and the coagulation system. Disruption of the endothelial continuity leads to exposure of collagen fibers and other subendothelial matrix proteins (Ruggeri 2002). Circulating platelets rapidly adhere to these structures and start the 
hemostatic process. Platelets immediately aggregate to form thrombi. Therefore, platelets have a wide array of surface receptors and adhesion molecules and contain numerous granules (Saboor et al. 2013; Sharda and Flaumenhaft 2018). Additional coagulation (clotting) factors respond in a cascade to form fibrin strands, which strengthen the platelet plug (Macfarlane 1964).

\section{Platelet adhesion}

Platelet adhesion to the extracellular matrix arranges a first, thin cover of the defect ECs. In this process, the von Willebrand factor (VWF) is essential (Sakariassen et al. 1979). VWF is a multimeric glycoprotein and is synthesized by ECs and stored in characteristic endothelial ultrastructural features, the Weibel-Palade bodies (Weibel and Palade 1964). VWF is also synthesized by megakaryocytes and localized in $\alpha$-granules of platelets (Wagner and Marder 1984). Injured ECs release VWF by vasoactive agents, such as bradykinin, histamine, vasopressin, or thrombin, which enhance the cytoplasmic $\mathrm{Ca}^{2+}$ level and activate protein kinase $\mathrm{C}$ (Birch et al. 1992). During this release process, Weibel-Palade bodies fuse with the plasma membrane and release VWF. Under the conditions of high shear stress, plasma VWF binds with its A3-domain to exposed subendothelial collagen and participates in interaction between platelets and ECs. This process induces uncoiling of VWF, and VWF exposes its A1-domain, which binds platelet VWF receptor, the glycoprotein (GP)Ib-V-IX complex. VWF serves as a bridge between subendothelial collagen and the platelet via GPIb $\alpha$ (subunit of the GPIb-V-IX) complex) at the platelet surface (Lankhof et al. 1996) (Fig. 2).

Therefore, it is not surprising that defects or dysfunction of the GPIb-V-IX complex are associated with a bleeding disorder, named Bernard-Soulier syndrome, which is characterized by thrombocytopenia and giant platelets. As a consequence, platelets are unable to adhere and a bleeding phenotype results (Zieger et al. 2009). The von Willebrand disease is caused by a quantitative a quantitative (reduction of VWF antigen) or qualitative (reduction of VWF activity) defect of VWF and is also characterized by bleeding symptoms (Goodeve and James 1993).

Interestingly, the interaction between subendothelial collagen, VWF, and platelets via the GPIb-V-IX complex is transient and does not lead to a stable adhesion; however, it facilitates efficient recruitment of platelets from the circulation to the damaged area (Savage et al. 1996). The localization of platelets close to the extracellular matrix allows now direct collagen interaction with the platelet membrane receptor GPVI (Nieswandt and Watson 2003). Binding of GPVI to collagen triggers the activation of the second platelet collagen receptor $\alpha_{2} \beta_{1}$ (GPIa/IIa), which is important for firm adhesion of platelets to the collagen surface (Kainoh et al. 1992) and of the platelet fibrinogen receptor integrin $\alpha_{\mathrm{II}} \beta_{3}$, which further strengthens adhesion (Goto et al. 2002). When platelets adhere to the subendothelial matrix, they change their shape from discoid to spherical (Ehrman et al. 1978). The platelet cytoplasm expands, and the cytoskeleton rearranges to develop fingerlike protrusions, filopodia and lamellipodia. The adhesion receptors are redistributed in lipid rafts and concentrate to the terminal parts of filopodia. These changes in shape are essential to make platelets more adherent to the injured area and to other platelets, thus increasing the surface area of platelets protecting the injured endothelium and preventing further blood loss.

\section{Platelet activation}

Interaction of collagen with platelets via GPVI and $\alpha_{2} \beta_{1}$ induces intracellular signaling and potentiates platelet leading to $\alpha$ - and $\delta$-granule secretion into the blood plasma. Platelet $\alpha$-granules contain adhesive glycoproteins, such as fibrinogen, VWF, coagulation factors, P-selectin, angiogenetic factors, mitogenic factors, fibrinolytic inhibitors, and immunoglobulins. $\delta$-granules are the storage pool of a variety hemostatically active nonprotein molecules, which are released during platelet activation. Those include catecholamines like serotonin and histamine, ADP, ATP, and $\mathrm{Ca}^{2+}$. Secreted agonists in turn activate surrounding platelets and trigger additional degranulation in terms of a positive feedback loop during platelet activation (Flaumenhaft 2003; Ruggeri 2002).

ADP released from damaged endothelial cells and $\delta$-granules from activated platelets plays a central role in regulating platelet function. Via their platelet purinergic receptors, $\mathrm{P}_{2} \mathrm{Y}_{1}$ and $\mathrm{P} 2 \mathrm{Y}_{12}$, ADP causes platelet shape change, aggregation, and generation of thromboxane $\mathrm{A}_{2}$ $\left(\mathrm{TxA}_{2}\right.$ ), another platelet agonist (Packham \& Mustard 2005).

Analogous to ADP, $\mathrm{TxA}_{2}$ can also (auto-)activates platelets. Upon platelet activation, $\mathrm{TxA}_{2}$ is synthesized from arachidonic acid, which is liberated from the plasma membrane through conversion by cyclooxygenase- $1(\mathrm{COX}-1)$. Tx $\mathrm{A}_{2}$ interacts with the thromboxane $\mathrm{A}_{2}$ receptor (TP) (FitzGerald 1991).

Another strong stimulator of platelets is thrombin, which is the final product of the coagulation system and responsible for converting fibrinogen into fibrin to stabilize the platelet plugs (Mann, Butenas and Brummel 2003). Thrombin interacts with protease-activated receptor 1 and 4 (PAR1 and PAR4), which enhance the release of VWF. This results in exposure of adhesion molecules at the platelet surface (ICAM-1, VCAM-1, E-selectin, P-selectin) and production of plasminogen activator inhibitor type-1 (PAI-1) (Leger et al. 2006). ECs express PAI-1, which functions as principal inhibitor of t-PA and u-PA activity and prevents fibrinolysis (Sprengers and Kluft 1987). Elevated levels of circulating PAI-1 are a risk factor for thrombosis and atherosclerosis (Vaughan 2005). 


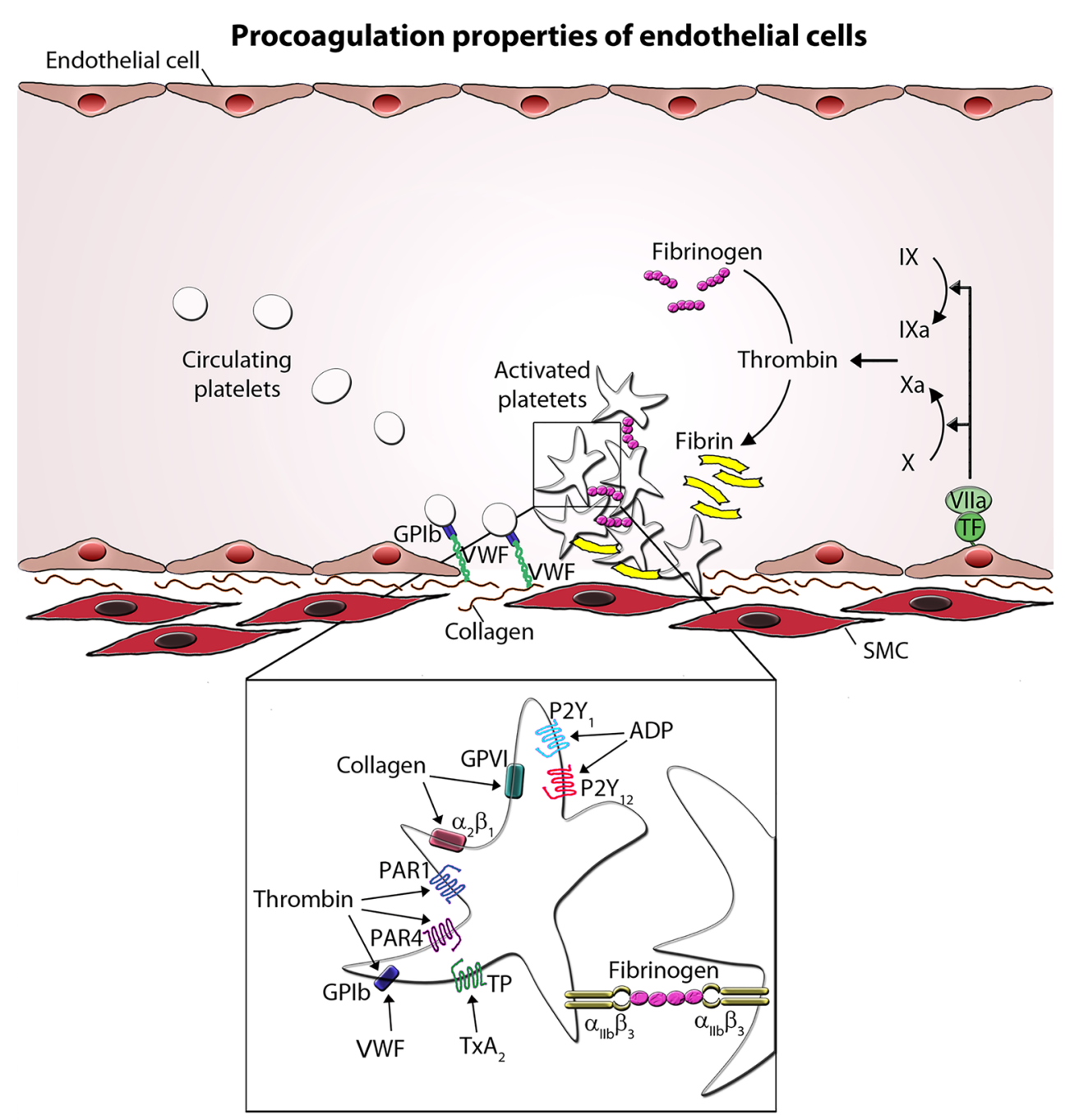

Fig. 2 Procoagulation properties of endothelial cells. At sites of vascular injury, Von Willebrand factor (VWF) binds to the exposed subendothelial collagen. VWF then captures platelets from the circulation via the interaction of the VWF with GPIb on the platelet. The binding of GPVI with collagen leads to further platelet activation. This results in the integrin-mediated adhesion of platelets and cellular activation releasing mediators. Selected platelet agonists and

Additionally, ECs and platelets synthesize plateletactivating factor (PAF), a phospholipid mediator that promotes the adhesion of platelets to the ECs and their activation and aggregation (Agarwal et al. 1994).

During activation, platelets secrete serotonin (5-hydoxytryptamine, 5-HT) from their $\delta$-granules, which is considered a weak platelet agonist, but with the ability to enhance the aggregation-response of platelets to other agonists, like ADP (Vanags et al. 1992).

These described soluble agonists trigger platelet activation through their $\mathrm{G}$ protein coupled receptors, resulting in increased $\mathrm{Ca}^{2+}$ concentrations in the platelets' cytosol which in turn activate specific signaling pathways their receptors are indicated. Thrombin binds to GPIb and activates protease-activated receptor 1 and 4 (PAR1 and PAR4, respectively), ADP activates $\mathrm{P}_{2} \mathrm{Y}_{1}$ and $\mathrm{P} 2 \mathrm{Y}_{12}$ receptor, and thromboxane $\mathrm{A}_{2}\left(\mathrm{TxA}_{2}\right)$ activates the thromboxane receptor (TP). Agonist stimulation results in integrin $\alpha_{\mathrm{IIb}} \beta_{3}$ activation and the transition to an active conformation, which binds fibrinogen and mediates platelet aggregate formation. SMC smooth muscle cell

promoting plug formation (Offermanns 2006; Varga-Szabo et al. 2009).

Platelet activation further results in redistribution of phospholipids to their outer membrane, for example, phosphatidylserine, which is essential for platelet adhesion and thrombus formation, since it promotes assembly of prothrombinase complexes on the platelet surface (Heemskerk et al. 1997).

\section{Platelet aggregation}

Aggregation of platelets begins shortly after activation and occurs as a result of the conformational change of the 
fibrinogen receptor integrin $\alpha_{\mathrm{II}} \beta_{3}$ (GPIIb/IIIa) at the platelet surface (Joo 2012; Nieswandt et al. 2009). In resting platelets, $\alpha_{\text {IIb }} \beta_{3}$ exists in an inactive conformation, unable to bind to its circulating plasma ligands, fibrinogen, and VWF. During activation, the extracellular domain of $\alpha_{\mathrm{IIb}} \beta_{3}$ transits from its resting to an active form by phosphorylation of its cytoplasmic domain, a process called "inside-out" signaling, resulting in increased affinity for its ligands. Furthermore, the surface density of active $\alpha_{\mathrm{IIb}} \beta_{3}$ increases during platelet activation. Bound fibrinogen or VWF to functional $\alpha_{\text {IIb }} \beta_{3}$ cross-links platelets and is essential for triggering then "outside-in signaling" and subsequent thrombus formation and stabilization. The importance of integrin $\alpha_{\mathrm{IIb}} \beta_{3}$ becomes apparent in a severe platelet disorder named Glanzmann thrombasthenia that is characterized by lack of platelet aggregation. The molecular basis is linked to quantitative and/or qualitative abnormalities of $\alpha_{\mathrm{II}} \beta_{3}$ (Sandrock-Lang et al. 2015).

Once a platelet plug has been formed, activation of the coagulation cascade is necessary to stabilize this plug by producing a fibrin mesh. Coagulation requires the sequential activation of blood-based serine proteases and their cofactors (blood clotting factors).

\section{Coagulation cascade}

Activation of the coagulation cascade results in the formation of fibrin from the plasma protein fibrinogen (Macfarlane 1964). The major initiator of this clotting process is TF. In the intact vessel wall, TF is hidden and is exposed to blood in response to injury. Platelets and coagulation factors leak into the subendothelial compartment, where membrane-bound TF can directly bind to coagulation factor VII. The TF-VIIa complex converts circulating factor IX and $\mathrm{X}$ into active enzymes, factors IXa and Xa (Fig. 2). Factor IXa further enhances the activation of factor X. Factor Xa subsequently catalyzes the generation of thrombin (factor IIa) from the zymogen prothrombin. Thrombin is the key enzyme since it cleaves fibrinogen into fibrin. Fibrin polymerizes into a fibrin network, which forms the blood clot with the aggregating platelets. Furthermore, thrombin is responsible for the conversion of factors V, VIII, XI, and XIII into their active form. VWF plays not only a major role in initial platelet recruitment but also in formation of the fibrin clot by associating with VIII and preventing its rapid clearance from the circulation (Tuddenham et al. 1982). When healing progresses, the thrombus can be degraded again by proteases, especially plasmin.

\section{Conclusion}

Vascular ECs form a dynamic lining at the interface between tissue and blood. They maintain blood fluidity and protect against injury of the vessel wall through delicate regulation of platelet activity, blood coagulation, and thrombolysis. Their effect on coagulation is the resultant or balance of multiple mechanisms, both anticoagulant and procoagulant. Loss of normal endothelial function or dysfunction of platelet may result in severe bleeding symptoms in humans (Sandrock-Lang et al. 2016).

Funding Open Access funding enabled and organized by Projekt DEAL. The authors' research work is supported by grants from the Deutsche Forschungsgemeinschaft (DFG/ZI 486/4-1 and DFG/ZI 486/8-1).

\section{Declarations}

Compliance with ethical standards and disclosure of interests None of the authors has any competing interests to declare. Since this article is a literature review, no ethical approval or declaration of informed consent is required.

Open Access This article is licensed under a Creative Commons Attribution 4.0 International License, which permits use, sharing, adaptation, distribution and reproduction in any medium or format, as long as you give appropriate credit to the original author(s) and the source, provide a link to the Creative Commons licence, and indicate if changes were made. The images or other third party material in this article are included in the article's Creative Commons licence, unless indicated otherwise in a credit line to the material. If material is not included in the article's Creative Commons licence and your intended use is not permitted by statutory regulation or exceeds the permitted use, you will need to obtain permission directly from the copyright holder. To view a copy of this licence, visit http://creativecommons.org/licenses/by/4.0/.

\section{References}

Adams TE, Huntington JA (2006) Thrombin-cofactor interactions: structural insights into regulatory mechanisms. Arterioscler Thromb Vasc Biol 26:1738-1745

Agarwal KC, Clarke E, Rounds S, Parks RE Jr, Huzoor A (1994) Platelet-activating factor (PAF)-induced platelet aggregation. Modulation by plasma adenosine and methylxanthines. Biochem Pharmacol 48:1909-1916

Aird WC (2015) Endothelium and haemostasis. Hamostaseologie 35:11-16

Anastasiou G, Gialeraki A, Merkouri E, Politou M, Travlou A (2012) Thrombomodulin as a regulator of the anticoagulant pathway: implication in the development of thrombosis. Blood coagulation \& fibrinolysis : an international journal in haemostasis and thrombosis $23: 1-10$

Bauer KA, Rosenberg RD (1991) Role of antithrombin III as a regulator of in vivo coagulation. Semin Hematol 28:10-18

Birch KA, Pober JS, Zavoico GB, Means AR, Ewenstein BM (1992) Calcium/calmodulin transduces thrombin-stimulated secretion: studies in intact and minimally permeabilized human umbilical vein endothelial cells. J Cell Biol 118:1501-1510

Braune S, Kupper JH, Jung F (2020) Effect of Prostanoids on Human Platelet Function: An Overview. International journal of molecular sciences 21:

Deaglio S, Robson SC (2011) Ectonucleotidases as regulators of purinergic signaling in thrombosis, inflammation, and immunity. Adv Pharmacol 61:301-332 
Durand MJ, Gutterman DD (2013) Diversity in mechanisms of endothelium-dependent vasodilation in health and disease. Microcirculation 20:239-247

Ehrman M, Toth E, Frojmovic M (1978) A platelet procoagulant activity associated with platelet shape change. J Lab Clin Med 92:393-401

Fetalvero KM, Martin KA, Hwa J (2007) Cardioprotective prostacyclin signaling in vascular smooth muscle. Prostaglandins Other Lipid Mediat 82:109-118

FitzGerald GA (1991) Mechanisms of platelet activation: thromboxane $\mathrm{A} 2$ as an amplifying signal for other agonists. Am J Cardiol $68: 11 \mathrm{~B}-15 \mathrm{~B}$

Flaumenhaft R (2003) Molecular basis of platelet granule secretion. Arterioscler Thromb Vasc Biol 23:1152-1160

Furchgott RF, Zawadzki JV (1980) The obligatory role of endothelial cells in the relaxation of arterial smooth muscle by acetylcholine. Nature 288:373-376

Ghosh DK, Salerno JC (2003) Nitric oxide synthases: domain structure and alignment in enzyme function and control. Front Biosci 8:d193-209

Girard TJ, Broze GJ Jr (1993) Tissue factor pathway inhibitor. Methods Enzymol 222:195-209

Gomez-Salinero JM, Rafii S (2018) Endothelial cell adaptation in regeneration. Science 362:1116-1117

Goodeve A, James P (1993) von Willebrand Disease. In: Adam MP, Ardinger HH, Pagon RA, Wallace SE, Bean LJH, Mirzaa G, Amemiya A (eds) GeneReviews((R)), Seattle (WA)

Goto S, Tamura N, Handa S, Arai M, Kodama K, Takayama H (2002) Involvement of glycoprotein VI in platelet thrombus formation on both collagen and von Willebrand factor surfaces under flow conditions. Circulation 106:266-272

Griffin JH, Evatt B, Zimmerman TS, Kleiss AJ, Wideman C (1981) Deficiency of protein $\mathrm{C}$ in congenital thrombotic disease. J Clin Investig 68:1370-1373

Heemskerk JW, Vuist WM, Feijge MA, Reutelingsperger CP, Lindhout $\mathrm{T}$ (1997) Collagen but not fibrinogen surfaces induce bleb formation, exposure of phosphatidylserine, and procoagulant activity of adherent platelets: evidence for regulation by protein tyrosine kinase-dependent $\mathrm{Ca} 2+$ responses. Blood 90:2615-2625

Hofsteenge J, Taguchi H, Stone SR (1986) Effect of thrombomodulin on the kinetics of the interaction of thrombin with substrates and inhibitors. Biochem J 237:243-251

Joo SJ (2012) Mechanisms of platelet activation and integrin alphaIIbeta3. Korean Circ J 42:295-301

Kainoh M, Ikeda Y, Nishio S, Nakadate T (1992) Glycoprotein Ia/ IIa-mediated activation-dependent platelet adhesion to collagen. Thromb Res 65:165-176

Lankhof H, van Hoeij M, Schiphorst ME, Bracke M, Wu YP, Ijsseldijk MJ, Vink T, de Groot PG, Sixma JJ (1996) A3 domain is essential for interaction of von Willebrand factor with collagen type III. Thromb Haemost 75:950-958

Leger AJ, Covic L, Kuliopulos A (2006) Protease-activated receptors in cardiovascular diseases. Circulation 114:1070-1077

Loskutoff DJ, Edgington TE (1977) Synthesis of a fibrinolytic activator and inhibitor by endothelial cells. Proc Natl Acad Sci USA 74:3903-3907

Loskutoff DJ, Edgington TS (1981) An inhibitor of plasminogen activator in rabbit endothelial cells. J Biol Chem 256:4142-4145

Macfarlane RG (1964) An enzyme cascade in the blood clotting mechanism, and its function as a biochemical amplifier. Nature 202:498-499

Mann KG, Butenas S, Brummel K (2003) The dynamics of thrombin formation. Arterioscler Thromb Vasc Biol 23:17-25

Marcus AJ, Safier LB, Hajjar KA, Ullman HL, Islam N, Broekman MJ, Eiroa AM (1991) Inhibition of platelet function by an aspirin-insensitive endothelial cell ADPase. Thromboregulation by endothelial cells. J Clin Investig 88:1690-1696
Medcalf RL (2007) Fibrinolysis, inflammation, and regulation of the plasminogen activating system. J. Thromb. Haemost. 5(Suppl 1):132-142

Mehta D, Malik AB (2006) Signaling mechanisms regulating endothelial permeability. Physiol Rev 86:279-367

Moncada S, Gryglewski R, Bunting S, Vane JR (1976) An enzyme isolated from arteries transforms prostaglandin endoperoxides to an unstable substance that inhibits platelet aggregation. Nature 263:663-665

Moncada S, Higgs EA, Vane JR (1977) Human arterial and venous tissues generate prostacyclin (prostaglandin $\mathrm{x}$ ), a potent inhibitor of platelet aggregation. Lancet 1:18-20

Nieswandt B, Varga-Szabo D, Elvers M (2009) Integrins in platelet activation. J. Thromb. Haemost. 7(Suppl 1):206-209

Nieswandt B, Watson SP (2003) Platelet-collagen interaction: is GPVI the central receptor? Blood 102:449-461

Offermanns S (2006) Activation of platelet function through G protein-coupled receptors. Circ Res 99:1293-1304

Ofosu FA, Modi GJ, Smith LM, Cerskus AL, Hirsh J, Blajchman MA (1984) Heparan sulfate and dermatan sulfate inhibit the generation of thrombin activity in plasma by complementary pathways. Blood 64:742-747

Packham MA, Mustard JF (2005) Platelet aggregation and adenosine diphosphate/adenosine triphosphate receptors: a historical perspective. Semin Thromb Hemost 31:129-138

Palmer RM, Ashton DS, Moncada S (1988) Vascular endothelial cells synthesize nitric oxide from L-arginine. Nature 333:664-666

Radomski MW, Palmer RM, Moncada S (1987) Endogenous nitric oxide inhibits human platelet adhesion to vascular endothelium. Lancet 2:1057-1058

Radomski MW, Palmer RM, Moncada S (1990) An L-arginine/nitric oxide pathway present in human platelets regulates aggregation. Proc Natl Acad Sci USA 87:5193-5197

Ruggeri ZM (2002) Platelets in atherothrombosis. Nat Med $8: 1227-1234$

Saboor M, Ayub Q, Ilyas S, Moinuddin, (2013) Platelet receptors; an instrumental of platelet physiology. PaK J Med Sci. 29:891-896

Sakariassen KS, Bolhuis PA, Sixma JJ (1979) Human blood platelet adhesion to artery subendothelium is mediated by factor VIIIVon Willebrand factor bound to the subendothelium. Nature 279:636-638

Sandrock-Lang K, Oldenburg J, Wiegering V, Halimeh S, Santoso S, Kurnik K, Fischer L, Tsakiris DA, Sigl-Kraetzig M, Brand B, Buhrlen M, Kraetzer K, Deeg N, Hund M, Busse E, Kahle A, Zieger B (2015) Characterisation of patients with Glanzmann thrombasthenia and identification of 17 novel mutations. Thromb Haemost 113:782-791

Sandrock-Lang K, Wentzell R, Santoso S, Zieger B (2016) Inherited platelet disorders. Hamostaseologie 36:178-186

Savage B, Saldivar E, Ruggeri ZM (1996) Initiation of platelet adhesion by arrest onto fibrinogen or translocation on von Willebrand factor. Cell 84:289-297

Sharda A, Flaumenhaft R (2018) The life cycle of platelet granules. F1000Research 7:236

Sprengers ED, Kluft C (1987) Plasminogen activator inhibitors. Blood 69:381-387

Stern D, Brett J, Harris K, Nawroth P (1986) Participation of endothelial cells in the protein C-protein S anticoagulant pathway: the synthesis and release of protein S. J Cell Biol 102:1971-1978

Towne JB, Bernhard VM, Hussey C, Garancis JC (1981) Antithrombin deficiency-a cause of unexplained thrombosis in vascular surgery. Surgery 89:735-742

Tuddenham EG, Lane RS, Rotblat F, Johnson AJ, Snape TJ, Middleton S, Kernoff PB (1982) Response to infusions of polyelectrolyte fractionated human factor VIII concentrate in human haemophilia A and von Willebrand's disease. Br J Haematol 52:259-267 
Vallance P, Collier J, Moncada S (1989) Effects of endotheliumderived nitric oxide on peripheral arteriolar tone in man. Lancet 2:997-1000

Vanags DM, Rodgers SE, Duncan EM, Lloyd JV, Bochner F (1992) Potentiation of ADP-induced aggregation in human platelet-rich plasma by 5-hydroxytryptamine and adrenaline. Br J Pharmacol 106:917-923

Varga-Szabo D, Braun A, Nieswandt B (2009) Calcium signaling in platelets. J. Thromb. Haemost. 7:1057-1066

Vaughan DE (2005) PAI-1 and atherothrombosis. J. Thromb. Haemost. 3:1879-1883

Wagner DD, Marder VJ (1984) Biosynthesis of von Willebrand protein by human endothelial cells: processing steps and their intracellular localization. J Cell Biol 99:2123-2130
Weibel ER, Palade GE (1964) New Cytoplasmic Components in Arterial Endothelia. J Cell Biol 23:101-112

Wolinsky H (1980) A proposal linking clearance of circulating lipoproteins to tissue metabolic activity as a basis for understanding atherogenesis. Circ Res 47:301-311

Wu KK, Liou JY (2005) Cellular and molecular biology of prostacyclin synthase. Biochem Biophys Res Commun 338:45-52

Zieger B, Jenny A, Tsakiris DA, Bartsch I, Sandrock K, Schubart C, Schafer S, Busse A, Wuillemin WA (2009) A large Swiss family with Bernard-Soulier syndrome-correlation phenotype and genotype. Hamostaseologie 29:161-167

Publisher's Note Springer Nature remains neutral with regard to jurisdictional claims in published maps and institutional affiliations. 